\title{
Malaria vectors in the Democratic Republic of the Congo: the mechanisms that confer insecticide resistance in Anopheles gambiae and Anopheles funestus
}

\author{
Luisa Nardini ${ }^{1,2}$, Richard H. Hunt ${ }^{1,2}$, Yael L. Dahan-Moss ${ }^{1,2}$, Nanette Christie ${ }^{3}$, Riann N. Christian ${ }^{1,2}$,
} Maureen Coetzee ${ }^{1,2}$ and Lizette L. Koekemoer ${ }^{1,2^{*}}$

\begin{abstract}
Background: The Democratic Republic of the Congo (DRC) is characterized as a holoendemic malaria area with the main vectors being Anopheles funestus and members of the Anopheles gambiae complex. Due to political instability and socio-economic challenges in the region, knowledge of insecticide resistance status and resistance mechanisms in these vectors is limited. Mosquitoes were collected from a mining site in the north-eastern part of the country and, following identification, were subjected to extensive testing for the target-site and biochemical basis of resistance. Quantitative real-time PCR was used to assess a suite of 10 genes frequently involved in pyrethroid and dichlorodiphenyltrichloroethane (DDT) resistance in An. gambiae females and males. In An. funestus, gene expression microarray analysis was carried out on female mosquitoes.
\end{abstract}

Results: In both species, deltamethrin resistance was recorded along with high resistance and suspected resistance to DDT in An. gambiae and An. funestus, respectively. A total of $85 \%$ of An. gambiae carried the kdr mutations as either homozygous resistant (RR) (L1014S, L1014F or both) or heterozygous (RS), however only 3\% carried the rdl mutant allele (RS) and no ace-1 mutations were recorded. Synergist assays indicated a strong role for P450s in deltamethrin resistance in both species. In An. gambiae, analysis of transcription levels showed that the glutathione-S-transferase, GSTS1-2, produced the highest fold change in expression (7.6-fold in females and 31-fold in males) followed by GSTE2, thioredoxin peroxidase (TPX2), and cytochrome oxidases (CYP6M2 and CYP6P1). All other genes tested produced fold change values below 2. Microarray analysis revealed significant over-transcription of cuticular proteins as well as CYP6M7, CYP6P9a and CYP6P9b in insecticide resistant An. funestus.

Conclusions: These data show that high levels of deltamethrin resistance in the main malaria vector species, conferred by enzymatic detoxification, are present in the DRC.

Keywords: Anopheles funestus, Anopheles gambiae, Deltamethrin resistance, kdr, Metabolic resistance, P450s, GST

\section{Background}

The severe burden of malaria in Africa is related to a number of factors including the presence of welladapted vectors, human activities, such as deforestation,

\footnotetext{
*Correspondence: lizettek@nicd.ac.za

${ }^{1}$ Wits Research Institute for Malaria, School of Pathology, Faculty of Health Sciences, University of the Witwatersrand, Johannesburg 2000, South Africa

Full list of author information is available at the end of the article
}

agriculture and urbanization, and poor healthcare due to socio-economic and political factors [1,2]. Malaria transmission is further enhanced through "occupational activities" such as mining that bring humans and vectors into contact [1]. Widespread drug resistance in Plasmodium parasites and insecticide resistance in the vectors exacerbate the problem [3]. All these factors are relevant in the Democratic Republic of the Congo (DRC) which is characterized by high transmission (i.e. more than 1 case per 
1000 population per year) of Plasmodium falciparum by the highly efficient vectors, Anopheles funestus, Anopheles gambiae and Anopheles coluzzii [3, 4]. Vector control in the DRC is largely based on the use of long-lasting insecticide treated bed nets (LLINs) [3, 4], and to a lesser extent, indoor residual spraying (IRS) which is limited to areas where mining operations are present [5].

A number of mechanisms confer resistance to a small pool of insecticides and for this reason, insecticide resistance management is both challenging and essential. Pyrethroids, organochlorines, carbamates and organophosphates are the only four classes of insecticide approved for use in vector control [6]. In particular, there has been a strong reliance on the pyrethroids as they are the only class of insecticide approved for treating bed nets, which have been central to reducing malaria prevalence. The pyrethroids are fast acting, inexpensive and demonstrate low mammalian and environmental toxicity. All four classes have been used for IRS.

Dichlorodiphenyltrichloroethane (DDT) is highly effective against many malaria vector populations and is relatively cost effective, however due to safety concerns, it is allowed for use in IRS programmes only. Given that DDT and pyrethroid resistance is widespread, interest in the carbamates and organophosphates for IRS is growing (see Refs. [7-10]) and in 2013, carbamates and organophosphates were used by 12 and 13 countries, respectively [11]. However, the use of the latter two is disadvantageous from a cost point of view, and more recently, resistance to these insecticides has been reported $[12,13]$.

Insecticide resistance is largely based on target-site insensitivity due to the occurrence of mutations and/or through enhanced enzymatic detoxification. Altered acetylcholinesterase, knockdown resistance $(k d r)$ and mutations in the 'resistance to dieldrin' gene are all examples of target-site mutations. Knockdown resistance refers to point mutations in the voltage gated sodium channel (VGSC), the target of DDT and pyrethroids. Three mutations in the VGSC are well described, they are L1014S, L1014F and more recently, N1575Y [14]. The West African mutation results in a change from leucine to phenylalanine (L1014F) of the S6 segment [15] while the East African version occurs at the same codon but is a leucine to serine mutation (L1014S) [16]. Although the naming of the mutations as East and West was based initially on where they were found in Africa, studies have since shown that the mutations are not restricted to these areas. In addition, both mutations have been found in one population $[17,18]$. A number of studies have shown that $k d r$ is often present in the DDT- and pyrethroid-resistant phenotypes, but the use of synergists have shown that metabolic based mechanisms may also be responsible for resistance, even if the mutation is present [19-21]. Furthermore, many studies that evaluate the presence of $k d r$ do not evaluate the presence of metabolic mechanisms through the use of synergists, quantitative real-time PCR or biochemical methods [22-24]. The mutations have been found in An. gambiae, An. coluzzii and Anopheles arabiensis $[25,26]$.

The ace- $1^{R}$ mutation is a glycine to serine substitution at position 119 in acetylcholinesterase that is related to carbamate and organophosphate resistance [27]. Given that pyrethroid and DDT resistance are so common, interest in carbamates and organophosphates as alternatives for use in IRS has increased and monitoring for the ace- $1^{R}$ mutation has become important [13]. The mutation has been found in An. gambiae, An. coluzzii and An. arabiensis vector populations in Ghana [13], Burkina Faso [28, 29], Côte d'Ivoire [30] and at low frequency in Benin [31]. With the use of dieldrin banned for public health, the presence of mutations in the $\gamma$-amino butyric acid (GABA) receptor is often ignored [32]. However, it is interesting that where these mutations occur, they remain established, and they have the potential to confer cross-resistance to other insecticides (both agricultural and public health) with the same target site $[18,33]$.

Metabolic detoxification involves three large enzyme families: the cytochrome P450s, the glutathione S-transferases (GSTs) and the esterases. Knowledge of the identity and functions of the enzymes that confer resistance is an important aspect of vector control so that resistance can be managed, the potential for cross-resistance can be reduced, and novel insecticide targets can be investigated. It has been shown that some enzymes are able to directly metabolize particular insecticides. For example, GSTe2 [34] and CYP6M2 [35] are able to metabolize DDT and pyrethroids, and CYP6Z1 is able to metabolize DDT [36] however in numerous studies many detoxification enzymes are highly over-transcribed in the resistant phenotype, suggesting that multiple enzymes may play a role in the resistance phenotype. In $A n$. gambiae and $A n$. arabiensis, genes such as CYP6M2, CYP6P3 [20, 37, 38] and CYP4G16 [39, 40] are frequently found overtranscribed, while in An. funestus, CYP6P9a, CYP6P9b, GSTe2 [34, 41] and CYP6M7 [42] have been implicated in metabolic detoxification.

Often, vector status and insecticide resistance monitoring, when conducted, are not sufficiently comprehensive in many countries. This imposes limitations on successful decision-making in national and local vector management programmes. This project aims to contribute to the knowledge of vector composition, insecticide resistance status and mechanisms conferring resistance in vectors from north-eastern DRC. 


\section{Methods}

\section{Entomological surveys and mosquito collections}

Entomological surveys and collections were conducted at the Kibali Gold Mine in the Moto goldfields, north-eastern DRC ( $\left.\mathrm{NO3}^{\circ} 08.846^{\prime} \mathrm{E} 29^{\circ} 36.548^{\prime}\right)$ in March/April 2011 and July 2012. Adult collections were done by manual aspiration in and around mine houses and structures, as well as in the homes and structures of nearby communities. According to initial field identifications using morphological keys [43], An. gambiae complex and An. funestus group were collected. A sub-set of wild caught females of each group were used for standard WHO insecticide susceptibility bioassays while the remainder of the females (2011: An. gambiae complex $=101, A n$ funestus group $=101 ; 2012:$ An. gambiae complex $=88$, An. funestus group $=94$ ) were brought back to the insectary at the National Institute for Communicable Diseases (NICD) in Johannesburg for further analysis. For this purpose, females were separated into glass vials, blood fed and provided with moist filter paper for oviposition. Each family produced from a female was given a number for identification purposes.

\section{Species identification}

Mosquitoes were identified to species level by polymerase chain reaction (PCR) for the An. gambiae complex [44], An. coluzzii (previously M molecular form) or $A n$. gambiae s.s. (previously S form) [45], and the An. funestus group [46].

\section{Plasmodium falciparum sporozoite detection}

Enzyme-linked immunosorbent assay (ELISA) was used to detect the presence of $P$. falciparum [47, 48]. The head and thorax of individual mosquitoes were used, and in all assays, positive and negative controls were included. Reactions were assayed spectrophotometrically

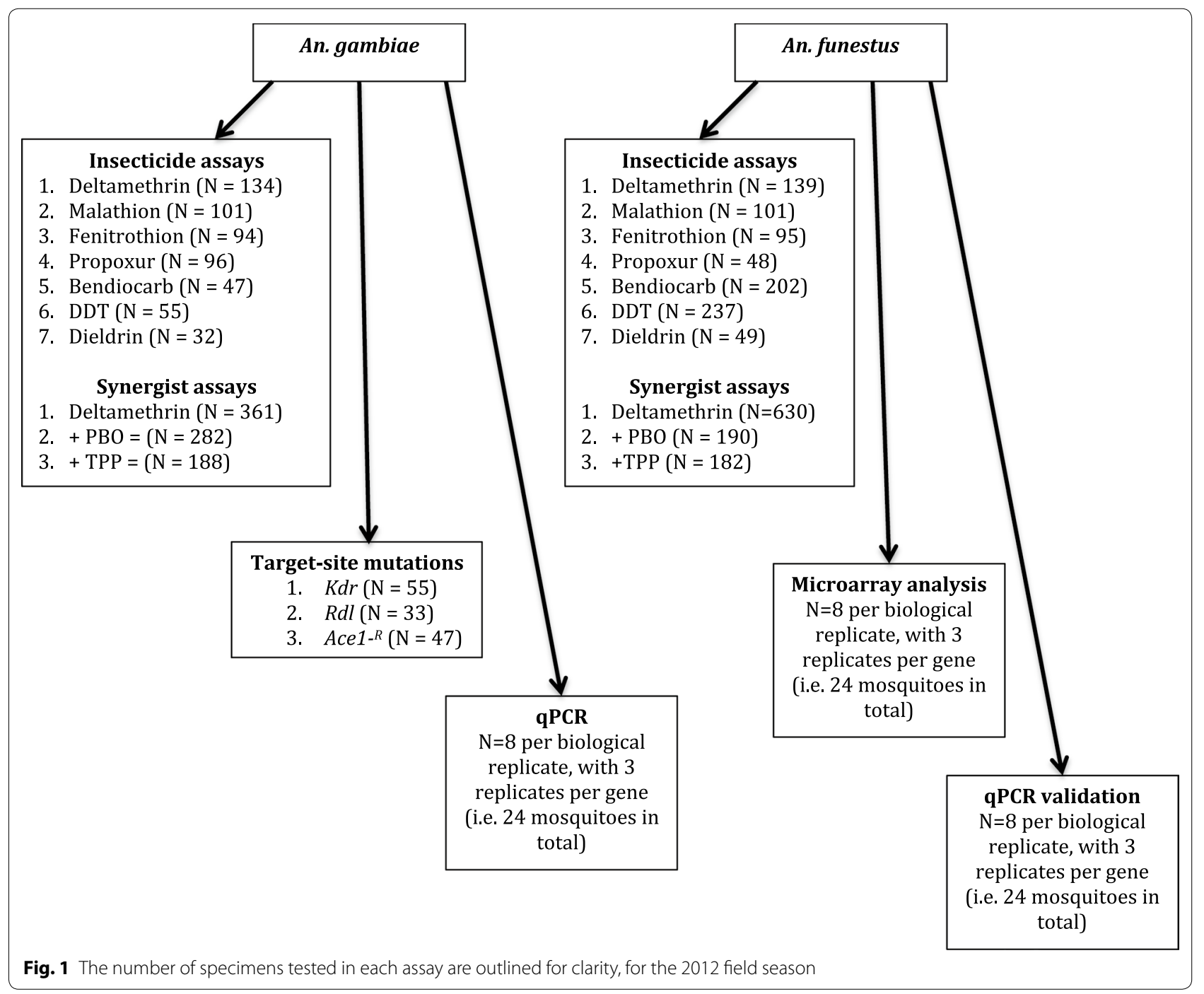


at $405 \mathrm{~nm}$ (Ascent Multiskan RC vl. 5.0, Genesis version 3.03, Labsystems) and all positive samples were assayed a second time.

\section{WHO bioassays and synergist exposures}

Where possible, field collected adults (males and females) of each species were exposed in the field to DDT (4\%), deltamethrin $(0.75 \%)$, propoxur $(0.1 \%)$, fenitrothion $(1 \%)$, malathion (5\%), bendiocarb $(0.1 \%)$ and dieldrin (4\%), according to standard WHO procedures [49]. In each case, mosquitoes were exposed to a particular insecticide for $1 \mathrm{~h}$ ( $2 \mathrm{~h}$ for fenitrothion), and sample sizes per exposure varied from 12 to 30 mosquitoes per tube depending on mosquito numbers. Mosquitoes were provided with a $10 \%$ sugar solution ad libitum and after $24 \mathrm{~h}$, mortality was recorded. During the 2012 collections, too few $A n$. gambiae were collected for field-based bioassays. For this reason, live specimens were returned to the laboratory and F1 progeny were used for insecticide exposures to DDT, deltamethrin, propoxur, fenitrothion, malathion, bendiocarb and dieldrin.

In the second survey (2012), F1 offspring from individual families generated from both $A n$. funestus and An. gambiae were used for synergist assays prior to deltamethrin exposure. These exposures comprised 1-4 day old males and females. Exposures were carried out as described above, however the number of replicate exposures varied for each family depending on the number of offspring available. These exposures were prepared in conjunction with synergist assays where the monooxygenase inhibitor, piperonyl butoxide (PBO) and the esterase inhibiter, triphenylphosphate (TPP) were used to synergize the F1 offspring of An. gambiae (PBO N = 282; TPP $\mathrm{N}=188$ ) and $A n$. funestus (PBO $\mathrm{N}=190$; TPP $\mathrm{N}=182$ ) prior to insecticide exposure. Between 5 and 20 adults were exposed, per replicate, to $4 \%$ PBO or $10 \%$ TPP for an hour depending on mosquito availability, and then immediately exposed to $0.75 \%$ deltamethrin for an hour before being returned to a holding tube. Mortality was recorded after $24 \mathrm{~h}$. Insecticide exposure versus synergist plus insecticide exposure were analysed using the Student's $t$-test. An outline of the key assays is provided in Fig. 1.

\section{Molecular evaluation of resistance mechanisms in Anopheles gambiae s.s.}

Both target site mutations and metabolic mechanisms were evaluated for the 2012 field season. Target site molecular markers were evaluated for the following alleles: $R d l$ (A296G), $k d r$ (L1014S and L1014F), ace- $1^{R}$ (G119S). Known metabolic genes (GSTS1-2, GSTE2, TPX2, CYP6M2, CYP6P1, CYP6AG2, CYP4G16, CYP9L1, $C Y P 6 Z 1$ and $S O D 1)$ were evaluated in F1 progeny using quantitative real-time PCR (qPCR).

\section{Detection of $k d r$}

Polymerase chain reaction (PCR) followed by direct sequencing of the relevant gene was performed in order to test for the presence of $k d r$ east and west mutations in specimens assayed against DDT in the An. gambiae field samples. DNA was extracted from both survivors $(\mathrm{N}=47)$ and mortalities $(\mathrm{N}=8)$, stored on silica gel, using the prepGEM Insect Kit (ZyGEM). Each PCR reaction (containing 2.5ul $10 \times$ PCR Buffer, $1.5 \mu \mathrm{l} \mathrm{MgCl}_{2}$ [25 mM], $2.5 \mu \mathrm{l}$ dNTP's [2.5 mM each], $3 \mu \mathrm{l}$ each of AGD1 and AGD2 primers [10 $\mu \mathrm{M}$ ], $0.2 \mu \mathrm{l}$ Takara Taq and $11.3 \mu \mathrm{l}$ nuclease free water) was subjected to the following cycling conditions: $94^{\circ} \mathrm{C} / 2 \mathrm{~min}(\mathrm{~min}),\left(94{ }^{\circ} \mathrm{C} / 30 \mathrm{~s}\right.$ [sec], $\left.50{ }^{\circ} \mathrm{C} / 30 \mathrm{~s}, 72{ }^{\circ} \mathrm{C} / 30 \mathrm{~s}\right) \times 40$ cycles, and a final extension step at $72{ }^{\circ} \mathrm{C}$ for $5 \mathrm{~min}$. The primers, AGD1 $\left(5^{\prime}\right.$ ATA GAT TCC CCG ACC ATG 3') and AGD2 (5' AGA CAA GGA TGA TGA ACC $3^{\prime}$ ), span the region containing the mutations [15]. Results were viewed by electrophoresis and column purified amplicons were sequenced in both directions by Macrogen (Sanger sequencing using the ABI 3730XL DNA Sequencing system). Sequences were aligned using DNASTAR (Lasergene Megalign 2007) software and were screened for the $k d r$. Positive and negative controls in the form of laboratory strains were included in order to assist with interpretation.

\section{Detection of "resistance to dieldrin" mutation}

The presence of the A296G mutation was assayed using TaqMan ${ }^{\circledR}$ technology according to the method of Bass et al. [50]. A mutant specific probe and wild type probe were included in the assay as well as two standard forward and reverse primers. Both survivors $(\mathrm{N}=1)$ and mortalities $(\mathrm{N}=32)$ were assayed and DNA was extracted using the prepGEM Insect Kit (ZyGEM). The resistant laboratory strain COGS (An. gambiae s.s. colonized from the Republic of the Congo in 2009 [18]) was used as a positive (homozygous resistant (RR) and heterozygous (RS) control while the susceptible SUA strain (An. coluzzii from Liberia) was used as a homozygous susceptible control (SS).

\section{Detections of ACE mutation}

PCR of the ace- $1^{R}$ mutation and subsequent digestion was performed in order to detect the G119S mutation in the acetylcholinesterase neurotransmitter [27]. DNA was extracted using the prepGem Insect Kit (ZyGEM) from mosquitoes that both survived $(\mathrm{N}=22)$ and died $(\mathrm{N}=25)$ following exposure to bendiocarb $(0.1 \%)$. Amplification of the ace- $1^{R}$ gene to produce a 541 base pair product was performed using the forward Ex3Agdir (5' GAT CGT GGA CAC CGT GTT CG 3') and reverse Ex3Agrev (5' AGG ATG GCC CGC TGG AAC AG $3^{\prime}$ ) primers under the following conditions: $94{ }^{\circ} \mathrm{C} / 3 \mathrm{~min}, 35$ 
cycles of $\left[94{ }^{\circ} \mathrm{C} / 30 \mathrm{~s}, 62{ }^{\circ} \mathrm{C} / 30 \mathrm{~s}, 72{ }^{\circ} \mathrm{C} / 20 \mathrm{~s}\right]$ and a final extension at $72{ }^{\circ} \mathrm{C} / 5 \mathrm{~min}$. Each reaction comprised $2.5 \mu \mathrm{l}$ $10 \times$ PCR Buffer, $2.5 \mu \mathrm{l}$ dNTPs [2.5 mM each], $1.5 \mu \mathrm{l}$ $\mathrm{MgCl}_{2}[25 \mathrm{mM}], 4 \mu \mathrm{l}$ of each primer at a concentration of $2 \mu \mathrm{M}, 0.2 \mu \mathrm{l}$ Takara Taq and $12.8 \mu \mathrm{l}$ nuclease-free $\mathrm{H}_{2} \mathrm{O}$. Digestion using Alu I (Promega) restriction enzyme was carried out and visualized with positive and negative controls by agarose gel electrophoresis. Restriction enzyme digestion produces two fragments of 403 and $138 \mathrm{bp}$ in the SS genotype, while three fragments (of 253, 150 and $138 \mathrm{bp}$ ) characterize the RR genotype.

\section{RNA extraction}

RNA was extracted from 1 to 5 day old An. gambiae F1 progeny using TRI ${ }^{\circledR}$ Reagent Solution (Sigma-Aldrich) [51]. For each of the three biological repeats, 2 mosquitoes from four different families were used $(\mathrm{N}=8)$, and for each biological repeat, four new families were used. A susceptible laboratory strain of An. coluzzii, SUA, was used as a control and three corresponding biological repeats were prepared. The RNA samples were reverse transcribed into cDNA using the QuantiTect ${ }^{\circledR}$ Reverse Transcription Kit (Qiagen) according to supplier instructions.

\section{Real-time quantitative PCR (qPCR)}

Real-time qPCR was used to evaluate transcription of 10 genes commonly known to, or previously implicated in playing a role in insecticide resistance against pyrethroids. Reference gene (RG) selection was performed as specified by the minimum information for publication of quantitative real-time PCR experiments [52] where the expression in 4 potential reference genes, namely ribosomal protein L19 (RPL19), ribosomal protein S7 (RPS7), $\beta$-actin and $18 S$ was evaluated and analysed using the MS Excel add-in, NormFinder [53]. For An. gambiae, RPL19 and $\beta$-actin showed the most stable transcription in both males and females. The over-transcription of the genes of interest was measured relative to these two RGs. Each qPCR reaction was set up as follows: $12.5 \mu \mathrm{IQ} \mathrm{IQ}^{\mathrm{TM}}$ SYBR super-mix (Bio-Rad), $4 \mu \mathrm{l}$ primer (concentration optimized for each gene), $1 \mu \mathrm{l} \mathrm{cDNA}(100 \mathrm{ng} / \mu \mathrm{l})$ and nuclease free water to a volume of $25 \mu \mathrm{l}$. PCR was carried out using the Bio-Rad CFX96 ${ }^{\mathrm{TM}}$ Real-Time PCR Detection System with the following cycling conditions: $93{ }^{\circ} \mathrm{C} / 3 \mathrm{~min}$, followed by 35 cycles of $\left[94{ }^{\circ} \mathrm{C} / 20 \mathrm{~s}\right.$, optimized annealing temperature $/ 25 \mathrm{~s}, 72{ }^{\circ} \mathrm{C} / 30 \mathrm{~s}$ ] with a single extension at $72{ }^{\circ} \mathrm{C} / 10 \mathrm{~min}$. and a final melt. Standard curves were prepared by 2 -fold dilutions of cDNA derived from the

Table 1 Primer sequences used for relative quantification of genes linked to the insecticide resistance phenotype in Anopheles gambiae

\begin{tabular}{|c|c|c|c|c|c|}
\hline Gene & Sequence $\left(5^{\prime}-3^{\prime}\right)$ & Primer conc. ( $\mu \mathrm{M})$ & Annealing temperature $\left({ }^{\circ} \mathrm{C}\right)$ & Amplicon size (bp) & Reference \\
\hline $\begin{array}{l}\text { GSTS1-2 F } \\
\text { GSTS1-2 R }\end{array}$ & $\begin{array}{l}\text { GCT GTC TTA CGG CAA CCT TC } \\
\text { CCA CGG TGT CAA TCA TCA AG }\end{array}$ & 3 & 58.3 & 212 & - \\
\hline GSTe2 F & CAT TTG AAG CCG GAA TTT GT & 3 & 60 & 123 & - \\
\hline GSTe2 R & TTT GCC ATA CTT CGT CAC CA & & & & \\
\hline $\begin{array}{l}\text { TPX2F } \\
\text { TPX2R }\end{array}$ & $\begin{array}{l}\text { GGA TGT TTG TGG GGA ATA CG } \\
\text { TGT GCG ATT AGC CTC CTC TT }\end{array}$ & 3 & 52 & 165 & [20] \\
\hline $\begin{array}{l}\text { CYP6M2 F } \\
\text { CYP6M2 R }\end{array}$ & $\begin{array}{l}\text { CAT GAC ACA AAC CGA CAA GG } \\
\text { GGT GAG GAG AGT CGA CGA AG }\end{array}$ & 3.5 & 52 & 235 & {$[20]$} \\
\hline CYP6P1 F & CGC GCA GGT GTTTAT CTTTTT & 3 & 60 & 199 & - \\
\hline CYP6P1 R & GTT CAC CAC CTG TCC GAG AT & & & & \\
\hline $\begin{array}{l}\text { CYP6AG2 F } \\
\text { CYP6AG2R }\end{array}$ & $\begin{array}{l}\text { TTG TGC TGC CGT ACT ATT CG } \\
\text { TAC TAT CGC CCG TCT CAC CT }\end{array}$ & 3 & 60 & 200 & {$[20]$} \\
\hline $\begin{array}{l}\text { CYP4G16 F } \\
\text { CYP4G16R }\end{array}$ & $\begin{array}{l}\text { CAG ACC GTC CAG CCA CAT TC } \\
\text { GCG AAC GAG CAATTA TAG GTA CTG }\end{array}$ & 3 & 60 & 108 & {$[20]$} \\
\hline $\begin{array}{l}\text { CYP9L1 F } \\
\text { CYP9L1 R }\end{array}$ & $\begin{array}{l}\text { AGA TAA TGT ATT CTT TCG CTA TGG } \\
\text { GCT CTT CTC GCT CTT GAA C }\end{array}$ & 3 & 56.3 & 188 & {$[20]$} \\
\hline CYP6Z1 F & TTA CATTCA CAC TGC ACG AG & 3 & 57 & 146 & - \\
\hline CYP6Z1 R & CTT CAC GCA CAA ATC CAG AT & & & & \\
\hline $\begin{array}{l}\beta \text {-actin F } \\
\beta \text {-actin R }\end{array}$ & $\begin{array}{l}\text { ACC AAG AGC CTG AAG CAC } \\
\text { CGA GCA CGA CAC ACT ATA TAC }\end{array}$ & N/A & - & 123 & {$[83]$} \\
\hline $\begin{array}{l}\text { RPL19F } \\
\text { RPL19 R }\end{array}$ & $\begin{array}{l}\text { CCA ACT CGC GAC AAA ACA TTC } \\
\text { ACC GGC TTC TTG ATG ATC AGA }\end{array}$ & N/A & - & 61 & [20] \\
\hline
\end{tabular}

The gene and primer names are designated as $F$ forward primer and $R$ reverse primer, and primer concentration (conc.), annealing temperature, amplicon size and primer citation are included where relevant. Annealing temperature of the reference genes $\beta$-actin and RPL19 were the same as that for each test gene (depicted as N/A) 
wild mosquitoes. For each gene, three biological repeats were assessed, and for each biological repeat, three technical repeats were included for each reaction. Data were analysed using the Pfaffl [54] method. Initially, columnpurified PCR product for each gene of interest was sent to Macrogen for Sanger sequencing in both directions in order to confirm (in addition to melt curve analysis) that the correct product was amplified in each case. The genes evaluated in male and female An. gambiae were GSTS1-2, GSTE2, TPX2, CYP6M2, CYP6P1, CYP6AG2, CYP4G16, CYP9L1, CYP6Z1 and SOD1. Primer sequences are provided in Table 1.

Evaluation of resistance mechanisms in Anopheles funestus As no $k d r$ has been found in An. funestus to date, this was not evaluated. The presence of $a c e-1^{R}$ or $r d l$ mutants was not included as An. funestus from this population were susceptible to bendiocarb and dieldrin, respectively.

\section{Preparation of microarrays and analysis}

RNA was extracted from 1 to 5 day old An. funestus F1 progeny [51]. For each of the three biological repeats, two mosquitoes from four different families were used $(\mathrm{N}=8)$, and for each biological repeat, four different families were used. A susceptible laboratory strain, FANG (An. funestus colonized from Angola in 2002), was used as a control and three corresponding biological repeats were prepared. RNA was extracted using the TRI ${ }^{\circledR}$ Reagent Solution (Sigma-Aldrich) according to supplier instruction, with a DNase treatment included (RNaseFree DNase Set, Qiagen). The quality and quantity of the RNA was assessed using a NanoDrop 2000 Spectrophotometer (Thermo Fisher Scientific Inc.). Four microarrays were prepared using the Agilent $4 \times 44 \mathrm{~K}$ platform (AMADID 048099) - one for each biological repeat, and a dye swap to account for bias in dye binding. Each array consisted of 33,022 An. funestus specific probes available in Genbank and 1417 Agilent control features. A total of
303 nucleotides belonged to the cytochrome P450 class, 11 to the GST class, 23 to the esterases class and a large number of other insecticide resistant genes.

Labelling was done using the Low Input Quick Amp Labelling Kit (Agilent Technologies) according to manufacturer's instructions. A starting quantity of $1 \mu \mathrm{g}$ RNA was incorporated into each labelling reaction. Labelled targets were purified using the RNEasy ${ }^{\circledR}$ Mini Kit (Qiagen) and successful labelling was evaluated using a NanoDrop Spectrophotometer (Thermo Fisher Scientific Inc.). Hybridization was performed provided dye incorporation was above $0.1 \mathrm{pmol} / \mu \mathrm{l}$ and cRNA yield above $36.2 \mathrm{ng} / \mu \mathrm{l}$. In addition, specific activity was determined as (concentration of $\mathrm{Cy} 3 / \mathrm{Cy} 5$ )/(concentration of RNA) $* 1000=$ pmol Cy3 or Cy5 per ug RNA. Specific activity above 8 pmol Cy3 or Cy5 per $\mu$ g RNA, with a yield above $825 \mathrm{ng}$ was acceptable. Hybridization was performed using the Agilent Gene Expression Hybridization Kit (Agilent Technologies) and was incubated at $65{ }^{\circ} \mathrm{C} / 18 \mathrm{~h}$. After this period, slides were washed and scanned using the GenePix 4000B scanner (Molecular Devices, USA) where the photomultiplier tube (PMT) settings were adjusted to give a pixel ratio of approximately 1 . Spot quality and background intensities were examined and corrected using GenePix Pro 6.0 software (Axon Instruments, USA). Saturated features were excluded from analysis (the PMT gain was set at maximum and minimum limits of 63,000).

Gene expression data were analysed using the limma (linear models for microarray data) package version 2.12.0 (Bioconductor) [55] in $\mathrm{R}$ version 2.8.0 [56]. Data were normalized ('within-array' global loess normalization and 'between-array' Aquantile normalization), and linear models were fitted in order to contrast resistant An. funestus expression values with expression values of a susceptible strain. Differentially expressed probes were defined as those with a fold-change greater or equal to 2 and with adjusted $p$-value $\leq 0.05$ [ $p$-values associated

Table 2 Primer sequences used for relative quantification of genes linked to the insecticide resistance phenotype in Anopheles funestus

\begin{tabular}{|c|c|c|c|c|c|}
\hline Gene & Sequence $\left(5^{\prime}-3^{\prime}\right)$ & Primer conc. ( $\mu \mathrm{M})$ & Annealing temperature $\left({ }^{\circ} \mathrm{C}\right)$ & Amplicon size (bp) & Reference \\
\hline $\begin{array}{l}\text { CYP6P9b F } \\
\text { CYP6P9b R }\end{array}$ & $\begin{array}{l}\text { CAG CGC GTA CAC CAG ATT GTG TAA } \\
\text { TTA CAC CTTTTC TAC CTT CAA GTA ATT ACC } \\
\text { CGC }\end{array}$ & 3 & 60 & 97 & {$[41]$} \\
\hline $\begin{array}{l}\text { CYP6M7F } \\
\text { CYP6M7 R }\end{array}$ & $\begin{array}{l}\text { CGTTGT ATG AGC TGG CGTTA } \\
\text { GTG CAT CTC CAT GAC AGC AT }\end{array}$ & 3 & 60 & 116 & {$[41]$} \\
\hline $\begin{array}{l}\text { RPL19 F } \\
\text { RPL19R }\end{array}$ & $\begin{array}{l}\text { CCA ACT CGC GAC AAA ACA TTC } \\
\text { ACC GGC TTC TTG ATG ATC AGA }\end{array}$ & 3 & - & 61 & {$[20]$} \\
\hline $\begin{array}{l}\text { RPS7 F } \\
\text { RPS7 R }\end{array}$ & $\begin{array}{l}\text { TTA CTG CTG TGT ACG ATG CC } \\
\text { GAT GGT GGT CTG CTG GTT C }\end{array}$ & 3 & - & 135 & {$[84]$} \\
\hline
\end{tabular}

The gene and primer names are designated as $F$ forward primer and $R$ reverse primer, and primer concentration (conc.), annealing temperature, amplicon size and primer citation are included where relevant 
Table 3 Mortality recorded in Anopheles gambiae s.s. males and females collected during the 2011 (adults collected in the field) and 2012 field (F1 progeny of field-collected adults) seasons following 1-h insecticide exposures using standard WHO tubes

\begin{tabular}{|c|c|c|c|c|c|c|}
\hline \multirow[t]{2}{*}{ Insecticide } & \multicolumn{3}{|c|}{2011} & \multicolumn{3}{|c|}{2012} \\
\hline & $\mathrm{N}$ & $\%$ Mortality & Resistance status & $\mathrm{N}$ & $\%$ Mortality & Resistance status \\
\hline Deltamethrin (0.75\%) & 97 & 51 & Resistant & 134 & 44 & Resistant \\
\hline Malathion (5\%) & 81 & 100 & Susceptible & 101 & 99 & Susceptible \\
\hline Fenitrothion (1\%) & 112 & 100 & Susceptible & 94 & 99 & Susceptible \\
\hline Propoxur (0.1\%) & 90 & 86 & Resistant & 96 & 100 & Susceptible \\
\hline Bendiocarb (0.1\%) & 90 & 97 & Suspected resistance & 47 & 53 & Resistant \\
\hline DDT (4\%) & 58 & 60 & Resistant & 55 & 15 & Resistant \\
\hline Dieldrin (0.4\%) & 52 & 100 & Susceptible & 32 & 97 & Suspected resistanc \\
\hline
\end{tabular}

Interpretation of resistance status is based on WHO criteria [49]

with the moderated $t$-test were corrected for multiple testing based on the false discovery rate (FDR)]. Batch Entrez [57] was used to retrieve the nucleotide sequences linked to accession numbers of all probes on the microarray $(25,404$ sequences were retrieved in FASTA format). Blast2GO [58] was used to functionally annotate the probe sequences, and for gene ontology (GO) enrichment of over- and under-transcribed gene sets. The $p$-values for the GO-enrichment analysis were calculated using Fisher's Exact Test and an adjustment for multiple testing was performed to control the FDR. In order to obtain additional annotation information, basic local alignment search tool (BLAST) [59] searches were carried out against all PEST and Aedes aegypti transcripts (FASTA files were downloaded from Vectorbase [60]). For each An. funestus query sequence, the top PEST and Aedes aegypti nucleotide BLAST hit was recorded if the e-value cutoff was less than 1e-05 (see Additional file 1).

\section{Real-time quantitative PCR (qPCR)}

Real-time PCR was used for validation of An. funestus microarray data as described above. Reference genes used for An. funestus were RPL19 and RPS7 as they were found to be the most stable RGs. The genes selected for microarray validation in $C Y P 6 M 7$ and $C Y P 6 P 9 b$, and primer details are summarized in Table 2.

\section{Results}

Species identification, WHO susceptibility tests and sporozoite detection

Anopheles gambiae complex

In 2011, 580 mosquitoes of unknown age were used for field-based bioassays. Although low levels of resistance will be missed by using wild adults, it does however provide valuable insight as to which resistance mechanisms needed to be targeted when F1 progeny were available [18]. During the 2012 survey, F1 progeny were used for bioassays $(\mathrm{N}=559)$ as the number of An. gambiae collected in the field were too few for meaningful bioassay tests to be conducted. Species identification was confirmed by PCR as An. gambiae s.s. (previously S molecular form). No An. coluzzii (M form) or An. arabiensis were identified. In 2011, the field bioassays indicated resistance to deltamethrin (51\% mortality), DDT (60\% mortality)

Table 4 Mortality recorded in Anopheles funestus males and females collected during the 2011 and 2012 field assays following 1-h insecticide exposures using standard WHO tubes

\begin{tabular}{|c|c|c|c|c|c|c|}
\hline \multirow[t]{2}{*}{ Insecticide } & \multicolumn{3}{|c|}{2011} & \multicolumn{3}{|c|}{2012} \\
\hline & $\mathbf{N}$ & $\%$ Mortality & Resistance status & $\mathbf{N}$ & $\%$ Mortality & Resistance status \\
\hline Deltamethrin $(0.75 \%)$ & 100 & 93 & Suspected resistance & 139 & 69 & Resistant \\
\hline Malathion (5\%) & 88 & 100 & Susceptible & 101 & 100 & Susceptible \\
\hline Fenitrothion (1\%) & 110 & 100 & Susceptible & 95 & 100 & Susceptible \\
\hline Propoxur (0.1\%) & 72 & 97 & Suspected resistance & 48 & 100 & Susceptible \\
\hline Bendiocarb (0.1\%) & 142 & 98 & Susceptible & 202 & 98 & Susceptible \\
\hline DDT (4\%) & 101 & 99 & Susceptible & 237 & 95 & Suspected resistance \\
\hline Dieldrin (0.4\%) & 49 & 100 & Susceptible & 49 & 100 & Susceptible \\
\hline
\end{tabular}

Interpretation of resistance status is based on WHO criteria [49] 
Table 5 Percentage mortality observed in F1 Aopheles gambiae and An. funestus males and females following exposure to the synergists (PBO or TPP) and insecticide

\begin{tabular}{llll}
\hline & $\mathbf{0 . 7 5 \%}$ Deltamethrin $\mathbf{( n )}$ & $\mathbf{0 . 7 5 \%}$ Deltamethrin + PBO (n) & $\mathbf{0 . 7 5 \% ~ D e l t a m e t h r i n ~ + ~ T P P ~ ( n ) ~}$ \\
\hline An. gambiae s.s. & $30 \%(361)^{\mathrm{a}}$ & $92 \pm 15 \%(282)^{\mathrm{b}}$ & $28 \pm 23 \%(188)^{\mathrm{a}}$ \\
An. funestus & $59 \%(630)^{\mathrm{a}}$ & $100 \pm 0 \%(190)^{\mathrm{b}}$ & $51 \pm 31 \%(182)^{\mathrm{a}}$ \\
\hline
\end{tabular}

a,b Indicate statistically significant differences determined by Students' $t$-test between deltamethrin $(0.75 \%)+$ synergist and deltamethrin $(0.75 \%)$ only
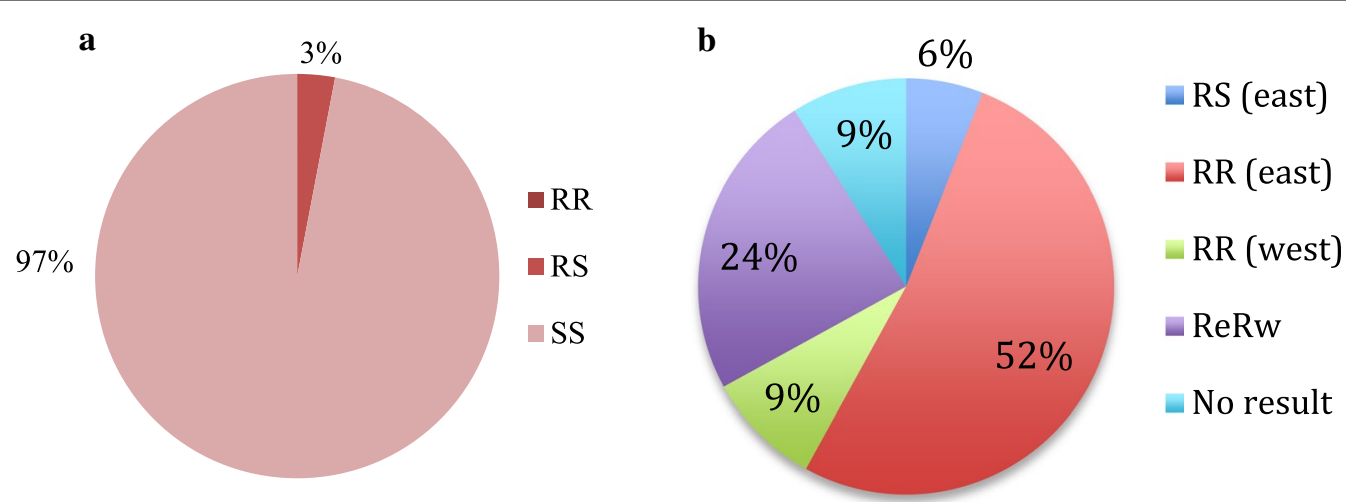

Fig. 2 Outcome of mutation assays for a $r d$ l mutant alleles and $\mathbf{b}$ kdr mutant east African (L1014S) and west African (L1014F) mutant alleles. In part (a), 3\% represents 1 specimen out of 33. In part $(\mathbf{b})$, representative specimen numbers are as follows: RS (east) $=3$, RR (east) $=29, R R$ (west) $=5$, ReRw $=13$, and 5 specimens failed to amplify (i.e. no result was obtained)

and propoxur (86\% mortality), with full susceptibility to the organophosphates (Table 3). The 2012 assessment revealed an even higher level of resistance to DDT $(15 \%$ mortality) while resistance to deltamethrin remained high (44\% mortality). In contrast, the mosquitoes reverted to propoxur susceptibility ( $86 \%$ in 2011 versus $100 \%$ mortality in 2012) but bendiocarb resistance had developed (97\% in 2011 versus $53 \%$ mortality in 2012). Full susceptibility to the organophosphates was maintained. An exceptionally high level of $P$. falciparum sporozoite positivity (8.8\%) was recorded in 2011.

\section{Anopheles funestus group}

A total 662 An. funestus were assayed for insecticide resistance in the field in 2011, while in 2012, a total of $871 A n$. funestus were tested in WHO bioassays. The mosquitoes were confirmed as An. funestus, and no other members of the An. funestus group were present. In the 2011 season, An. funestus were largely susceptible to all insecticides tested, although evidence of emerging deltamethrin resistance was observed with $93 \%$ mortality after 1 -h exposure (Table 4). Worryingly, full resistance to deltamethrin was observed in 2012 (with 69\% mortality) and potential resistance to DDT had emerged (95\% mortality). Susceptibility to the organophosphates was reported and maintained in 2011 and 2012. As in the case of An. gambiae, an unusually high percentage of mosquitoes (12.2\%) were found to be positive for $P$. falciparum in the 2011 field season.

\section{Synergist assays}

Use of the monooxygenase specific synergist, PBO, revealed that deltamethrin was largely based on $\mathrm{P} 450$ based metabolism with complete reversion to susceptibility after exposure to PBO in An. funestus, and almost complete reversion to susceptibility in An. gambiae (F1 progeny in both species used for these assays) (Table 5). Synergizing mosquitoes with TPP prior to deltamethrin exposure produced no change in susceptibility to deltamethrin.

\section{Molecular evaluation of resistance mechanisms in Anopheles gambiae \\ Rdl-mutation}

Only one mosquito survived dieldrin exposure in 2012, and was analysed for the presence of the $r d l$ mutation. Those that survived exposure $(\mathrm{N}=32)$ were also genotyped. The specimen that survived exposure to dieldrin was heterozygous for the mutation (Fig. 2a). All those that died were homozygous SS.

\section{Kdr-mutation}

Of the 55 specimens tested against DDT, 53\% were homozygous resistant for the east mutation $\left(R_{L} R_{1014 S}\right)$, while only $9 \%$ were homozygous for the west mutation $\left(\mathrm{RR}_{\mathrm{L} 1014 \mathrm{~F}}\right)$ (Fig. $\left.2 \mathrm{~b}\right)$. Heterozygotes for the east $\left(\mathrm{R}_{\mathrm{L} 1014 S} \mathrm{~S}\right)$ form were found $(6 \%)$, but none for the west mutant. A large percentage $(24 \%)$ of the specimens 
carried both mutations. The $k d r$ status for $9 \%$ could not be determined by sequencing or by TaqMan ${ }^{\circledR}$ assays.

\section{Ace- $1^{R}$ mutation}

There were no ace- $1^{R}$ mutants detected in any bendiocarb resistant specimens $(\mathrm{N}=47)$ from 2012 collections.

\section{Real-time quantitative PCR}

Genes that are frequently reported as playing a role in insecticide resistance to pyrethroids were selected for analysis by real-time quantitative PCR in An. gambiae males and females. In males, a greater than 5 -fold increase was observed in GSTS1-2, GSTe2, TPX2 and CYP6M2 when compared with the selected reference genes (RGs). In females, GSTS1-2 and GSTe2 showed over-transcription greater than 5-fold, while TPX2, CYP6M2 and CYP6P1 were more than 2-fold over-transcribed relative to the selected RGs (Fig. 3).

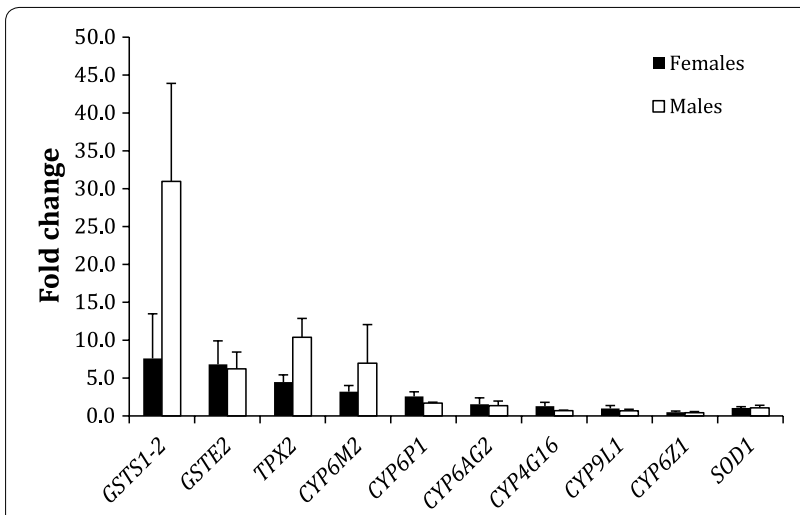

Fig. 3 The fold change reported for adult An. gambiae male and female specimens from the DRC. Genes that are frequently reported as playing a role in insecticide resistance to pyrethroids were selected for analysis. The fold change (FC) values reported here represent the average FC values measured against two different reference genes (RGs) RSP7 and RPL 19 (three biological repeats per RG). Bars represent standard deviation

\section{Molecular evaluation of resistance mechanisms} in Anopheles funestus

Anopheles funestus gene expression arrays were prepared to evaluate changes in gene expression in resistant female An. funestus from the DRC using a susceptible laboratory strain as a reference. According to our criteria for cutoff ( $\mathrm{FC} \geq 2.0$ and adjusted $p$-value $\leq 0.05$ ), a total of 409 and 280 probes were significantly over- and under-transcribed respectively (Additional file 1). Using Blast2GO, enriched gene ontology terms were assigned to the sets of over- and under-transcribed genes. As expected, genes with a variety of functions produced significantly increased transcript abundance, although proteins with oxidoreductase activity, and cuticular proteins predominated ( $p$-value $<0.05$, FDR $<0.1)$ as determined by enrichment analyses (Table 6). Amongst the most highly over-transcribed genes were ubiquitin c (EZ916542), a component of the ubiquitin proteolytic system [61], at 8.4-fold over-transcribed; troponin C (EZ915656), an important protein in calcium dependent regulation of muscle contraction [62] at 5.7-fold over-transcribed; and the oxido-reductase enzyme sorbitol dehydrogenase, 8.2-fold over-transcribed (Table 7). Other highly transcribed non-detoxification genes included chymotrypsin 1 (7.3-fold over-transcribed), and a range of cuticle proteins. Five known cytochrome P450s were significantly over-transcribed, namely CYP6M7 (7.7-fold), CYP6P9b (3.3-fold), CYP6P9a (2.0-fold) and the duplicated genes, CYP6P4a and CYP6P4b, at 2.0- and 2.1-fold over-transcribed respectively (Table 8 ). The DDT-metabolizing GSTe2 was 2-fold over-transcribed, while a second GST, un-annotated in An. funestus, but which mapped to GSTs1 in An. gambiae was also significantly over-transcribed (3.6-fold) (Table 8).

Interestingly, a number of immunity related genes were found to be under-transcribed. These included serine proteases, including CLIPC7 and CLIPB1, a spondin, and trypsin and chymotrypsin like protein. In addition to these analyses, the microarray reporter sequences obtained here were blasted against An. gambiae (PEST) and Aedes aegypti genomes in order to supplement the annotations as the An. funestus reference genome is incomplete [63]. These annotations have been added to the Additional file 1.

Table 6 Significantly enriched gene ontology terms (GO) terms, using Blast2Go, of over-transcribed genes in insecticide resistant Anopheles funestus relative to susceptible controls

\begin{tabular}{llll}
\hline GO Description & GO Type & Adjusted $p$-value (FDR) & Cluster frequency \\
\hline Oxidoreductase activity & Molecular function & $3.0 \mathrm{E}-06$ & $16 / 929$ \\
Structural constituent of the cuticle & Molecular function & $7.7 \mathrm{E}-06$ & $4 / 24$ \\
Oxidation-reduction process & Biological process & $1.7 \mathrm{E}-05$ & $14 / 824$ \\
\hline
\end{tabular}


Table 7 The top 35 over-transcribed genes with available descriptions, in wild insecticide resistant Anopheles funestus relative to the susceptible laboratory strain, FANG

\begin{tabular}{|c|c|c|c|c|c|}
\hline Accession number & $\log _{2} \mathrm{FC}$ & FC & Adjusted p-value (FDR) & Best-hit Blast2Go description & Best-hit PEST descriptions \\
\hline EZ916542 & 3.07 & 8.4 & $4.6 \mathrm{E}-04$ & Ubiquitin c variant 2 & Polyubiquitin-B \\
\hline EZ976930 & 3.03 & 8.2 & $8.2 \mathrm{E}-05$ & Cuticular protein 49aa cg30045-pb & CPR113: cuticular protein RR-2 family 113 \\
\hline EZ967106 & 2.97 & 7.9 & $8.1 \mathrm{E}-05$ & - & Myosin heavy chain \\
\hline EZ980273 & 2.96 & 7.8 & $1.4 \mathrm{E}-02$ & $\begin{array}{l}\text { tbc domain-containing protein kinase- } \\
\text { like protein }\end{array}$ & $\begin{array}{l}\text { TBC domain-containing protein kinase-like } \\
\text { protein }\end{array}$ \\
\hline EZ973782 & 2.94 & 7.7 & $8.2 \mathrm{E}-05$ & Cytochrome p450 6 a8 & CYP6M3: cytochrome P450 \\
\hline EZ915918 & 2.89 & 7.4 & $1.3 \mathrm{E}-04$ & Actin & Actin, cytoplasmic \\
\hline EZ979664 & 2.86 & 7.3 & $8.1 \mathrm{E}-05$ & CHYMOTRYPSIN 1 & CHYM1: chymotrypsin-1 \\
\hline EZ915406 & 2.75 & 6.7 & $8.1 \mathrm{E}-05$ & Sorbitol dehydrogenase & D-xylulose reductase A \\
\hline EZ918406 & 2.70 & 6.5 & $8.1 \mathrm{E}-05$ & Ubiquitin c variant 2 & Polyubiquitin \\
\hline EZ980370 & 2.53 & 5.8 & $5.9 \mathrm{E}-03$ & Slow border cells & $\begin{array}{l}\text { CCAAT/enhancer binding protein (C/EBP), } \\
\text { invertebrate }\end{array}$ \\
\hline EZ917907 & 2.53 & 5.8 & $3.7 \mathrm{E}-04$ & Flightin & Flightin \\
\hline EZ919993 & 2.52 & 5.8 & 8.7E-05 & - & CPLCA3: cuticular protein 3 in CPLCA family \\
\hline EZ925592 & 2.51 & 5.7 & $1.2 \mathrm{E}-04$ & - & $\begin{array}{l}\text { NADH dehydrogenase (ubiquinone) } 1 \\
\text { alpha subcomplex } 4\end{array}$ \\
\hline EZ915656 & 2.51 & 5.7 & 8.7E-05 & Troponin c & Troponin C \\
\hline EZ917820 & 2.41 & 5.3 & $6.4 \mathrm{E}-04$ & - & CPR125: cuticular protein RR-2 family 125 \\
\hline EZ916349 & 2.37 & 5.2 & $9.0 \mathrm{E}-05$ & Actin & Actin, cytoplasmic \\
\hline EZ966655 & 2.36 & 5.1 & $4.4 \mathrm{E}-04$ & $\begin{array}{l}\text { Transforming growth factor beta regula- } \\
\text { tor } 1\end{array}$ & Uncharacterized protein \\
\hline EZ920676 & 2.30 & 4.9 & $6.9 \mathrm{E}-04$ & & Troponin T, fast skeletal muscle \\
\hline EZ966156 & 2.28 & 4.8 & $8.8 \mathrm{E}-03$ & Muscle lim protein & Muscle LIM protein at 84B \\
\hline EZ915396 & 2.24 & 4.7 & $1.2 \mathrm{E}-04$ & Sorbitol dehydrogenase & D-xylulose reductase A \\
\hline EZ917325 & 2.18 & 4.6 & $1.2 \mathrm{E}-04$ & $\begin{array}{l}\text { Regulator of microtubule dynamics } \\
\text { protein } 1 \text {-like }\end{array}$ & $\begin{array}{l}\text { Regulator of microtubule dynamics protein } \\
1 \text {-like }\end{array}$ \\
\hline EZ920255 & 2.18 & 4.5 & $1.2 \mathrm{E}-04$ & - & Muscle LIM protein at 84B \\
\hline EZ915403 & 2.15 & 4.4 & $1.2 \mathrm{E}-04$ & Sorbitol dehydrogenase & D-xylulose reductase A \\
\hline EZ917889 & 2.09 & 4.3 & $1.3 \mathrm{E}-04$ & - & Flightin \\
\hline EZ974390 & 2.04 & 4.1 & $2.9 \mathrm{E}-04$ & Stretchin-isoform d & Stretchin-isoform d \\
\hline EZ920519 & 2.00 & 4.0 & $1.3 \mathrm{E}-04$ & - & Actin, cytoplasmic \\
\hline EZ973962 & 1.99 & 4.0 & $2.9 \mathrm{E}-04$ & Dimeric dihydrodiol dehydrogenase & Dimeric dihydrodiol dehydrogenase \\
\hline EZ915590 & 1.98 & 3.9 & $1.6 \mathrm{E}-04$ & Venom allergen & A5R1: antigen 5 related protein 1 \\
\hline EZ915515 & 1.98 & 3.9 & $1.5 \mathrm{E}-04$ & - & $\begin{array}{l}\text { CPCFC1: cuticular protein CPCFC family } \\
\text { (CPCFC1) }\end{array}$ \\
\hline EZ924022 & 1.95 & 3.9 & $1.5 \mathrm{E}-04$ & Pupal cuticle & Pupal cuticle \\
\hline EZ916170 & 1.95 & 3.9 & $1.4 \mathrm{E}-04$ & Stretchin-isoform d & Stretchin-isoform d \\
\hline EZ915759 & 1.88 & 3.7 & $2.9 \mathrm{E}-04$ & - & $\begin{array}{l}\text { GSTS1: glutathione S-transferase sigma } \\
\text { class } 1\end{array}$ \\
\hline EZ976897 & 1.87 & 3.7 & $1.6 \mathrm{E}-04$ & $\begin{array}{l}\text { Leucine-rich repeat-containing protein } \\
\text { 20-like isoform } 1\end{array}$ & $\begin{array}{l}\text { Leucine-rich repeat-containing protein } \\
\text { 20-like isoform } 1\end{array}$ \\
\hline EZ973739 & 1.87 & 3.6 & $1.6 \mathrm{E}-04$ & Lysozyme c-4 & LYSC4: C-Type Lysozyme \\
\hline EZ915209 & 1.85 & 3.6 & $3.6 \mathrm{E}-04$ & Glutathione S-transferase & $\begin{array}{l}\text { GSTS1: glutathione S-transferase sigma } \\
\text { class } 1\end{array}$ \\
\hline
\end{tabular}

The complete gene list is included as Additional file 1

Validation of microarray data was carried out on CYP6P9b and CYP6M7. The FC values obtained for these were in line with those obtained by microarray analyses. Specifically, CYP6P9b showed 5.8 ( \pm 1.5 )-fold higher expression relative to FANG, and CYP6M7, $6.3( \pm 4.2)$-fold higher expression than that of FANG. These values are based on the use of two RGs in each case. 
Table 8 Cytochrome P450s and GSTs significantly over-transcribed in Anopheles funestus from DRC, when compared with the susceptible laboratory strain, FANG

\begin{tabular}{|c|c|c|c|c|}
\hline Accession number & Name & Annotated description & Annotation against PEST & $\mathrm{FC}$ \\
\hline EZ973782 & Afun007663 (CYP6M7) & Cytochrome P450 6a8 & CYP6M3 & 7.7 \\
\hline$J \times 627312$ & CYP6P9b & Cytochrome P450 & CYP6Р3 & 3.0 \\
\hline EF152577 & CYP6P13 (CYP6P9b) & Cytochrome P450 & - & 2.7 \\
\hline EZ975565 & Afun009522 & Cytochrome P450 & - & 2.6 \\
\hline EZ973498 & Afun007369 (CYP6P9a) & Cytochrome P450 & - & 2.3 \\
\hline EU852645 & CYP6P4b & Cytochrome P450 & - & 2.1 \\
\hline AY987359 & CYP6P4 & Cytochrome P450 & - & 2.0 \\
\hline EU852644 & CYP6P4a & Cytochrome P450 & - & 2.0 \\
\hline EZ915759 & cmb2_Irc578 & Glutathione S-transferase & GSTs1 & 3.7 \\
\hline EZ915209 & cmb2_Irc28 & Glutathione S-transferase & GSTs1 & 3.6 \\
\hline EZ979266 & Afun013481 (GSTe2) & Glutathione S-transferase & - & 2.0 \\
\hline
\end{tabular}

Criteria for significance were as follows: $\mathrm{FC} \geq 2$ and adjusted $p$-value $\leq 0.05$

\section{Discussion}

This study aimed to characterize malaria vector profiles, insecticide resistance status and the mechanisms conferring resistance in the vectors in the DRC. These data are not only essential for insecticide resistance management in the region, but also contribute to the growing body of knowledge focussed on pyrethroid resistance.

Both of the surveys carried out in 2011 and 2012 identified the major vectors $A n$. funestus and $A n$. gambiae s.s., as confirmed by PCR. The indoor house-spraying programme implemented after the initial field assessment in 2011 was based on the use of organophosphates and carbamates used in rotation. Both vector species were resistant to the Type II pyrethroid, deltamethrin. Of particular concern was the decrease in susceptibility to deltamethrin observed in An. funestus between 2011 and 2012-mortality dropped from 93\% (2011) to 59\% (2012). Such decreases in susceptibility can be due to over-use of a particular insecticide and in this instance, likely due to the widespread use of treated bed nets in the area, as well as the use of pyrethroids in both formal and informal agriculture. Anopheles funestus remained susceptible to all other insecticides tested, and critically, no changes in susceptibility to bendiocarb or the organophosphates were observed. In An. gambiae, the situation was more complex: mortality against DDT dropped from $60 \%$ (2011) to $15 \%$ (2012), and resistance to bendiocarb developed in the same period. In the absence of the use of DDT, the origin of resistance to the insecticide is not clear but may be related to cross-resistance conferred by pyrethroid resistance mechanisms such as $k d r$ and the over-transcription of the cytochrome P450, CYP6M2 [35]. The use of bendiocarb conferred rapid resistance to this insecticide, despite being used in rotation with the organophosphates. Such a situation emphasizes the need for regular resistance and vector monitoring so that adjustments to control programmes can be made timeously and accurately.

More than half of the An. gambiae samples assayed here were homozygous for the East African $k d r$ mutation (L1014S), while 6\% were heterozygous for this mutation. The West African $k d r$ mutation (L1014F) was homozygous in $9 \%$ of the specimens, but no heterozygotes were found. In their study of $k d r$ in the DRC, Basilua et al. [64] reported the presence of the L1014F (West African mutant) only, with the homozygous RR genotype predominating in 53\% of the test population in 2009 . Other studies of $k d r$ in the central African region have reported the presence of both alleles in Cameroon [22] and the Congo [18]. The use of synergist assays indicates that $k d r$ plays a limited role in pyrethroid resistance, but rather that cytochrome P450s are responsible. Carbamate resistance is most likely due to metabolic resistance and the absence of the ace- $1^{R}$ mutation supports this. Dieldrin is no longer used, but low levels of $r d l$-mutation were observed.

Further characterization of metabolic resistance mechanisms in both species were either through qPCR or microarray analysis. The use of microarray based studies and qPCR have provided relatively simple means to determine the identity of specific metabolic genes associated with resistance phenotypes. This is supported by the use of the synergist, $\mathrm{PBO}$, which resulted in a reversion to $100 \%$ mosquito mortality in the presence of pyrethroids for An. funestus and $92 \%$ in An. gambiae. It is thought that the duplicated and highly polymorphic $C Y P 6 P 9 a$ and $C Y P 6 P 9 b$ genes $[65,66]$, along with $C Y P 6 M 7$ are driving the spread of pyrethroid resistance northwards from Mozambique, Malawi and Zambia [41, 67]. Typically, both CYP6P9a and CYP6P9b are found to be 
over-transcribed in pyrethroid resistant An. funestus at much higher levels than those observed here [41] and this may reflect differing origins of resistance from resistant populations in southern Africa [68, 69], with decreasing over-transcription of these enzymes from Mozambique to Zambia $[41,68]$ to the DRC. A recent report by Riveron et al. [41] shows that both enzymes are able to confer resistance to pyrethroids independently and CYP6P9b is metabolically active against Type I and Type II pyrethroids. Similarly, CYP6M7 (over-transcribed by 7.7-fold) is metabolically active against the pyrethroids [41]. These data expand the previously reported northern range of over-transcribed CYP6P9a, CYP6P9b and CYP6M7 in An. funestus from Zambia to northeastern DRC.

GSTe2 has been well documented in the context of DDT resistance and elevated levels of transcription have been reported in An. funestus [34], An. gambiae [70] and Aedes aegypti [71]. GSTe2 has been closely linked to insecticide resistance in An. funestus from West Africa where elevated transcription, enhanced by a leucine to phenylalanine replacement (L119F), confers resistance to DDT and crossresistance to pyrethroids [34, 72]. The presence of L119F should be assessed in subsequent work in the DRC in order to determine if this mutation is present in the region, however, the fact that full reversion to pyrethroid susceptibility in the presence of $\mathrm{PBO}$ would suggest a negligible role for this enzyme in conferring pyrethroid resistance.

In their study of the sigma class GST 1 in Apis cerana cerana, Yan et al. [73] reported that the enzyme plays an important role in limiting oxidative damage and may play a role in detoxification of xenobiotics. Its specific function in Anopheles species is yet to be determined but the role of reducing oxidative damage is essential in protection against insecticides, particularly pyrethroids. Furthermore, the over-transcription of GSTS1-2 has been found in the DDT and pyrethroid resistant phenotype of An. arabiensis [20] and pyrethroid resistant An. gambiae [74], and combined with the present data, suggest a role in insecticide resistance, even if only as a secondary function.

Cuticle thickening has been detected in a number of resistant mosquito species and enhances resistance by increasing the barrier against insecticides at the point of contact. Over-transcription of cuticle genes has been reported in An. gambiae s.s. [75] and An. funestus [76] and through the use of scanning electron microscopy [77], shown that the cuticle of pyrethroid resistant $A n$. funestus was thicker than in susceptible mosquitoes. Larval and pupal cuticle-associated genes, along with a range of other cuticular genes were over-transcribed in a range of 2.1-8.2-fold.

Given the exceptionally high prevalence of malaria parasites in the vector populations in the area, and the fact that the data were generated from wild mosquitoes, it is interesting to note that a number of immune related genes were under-transcribed. Rivero et al. [78] proposed two explanations for this effect: 1) immunity may be compromized due to limitations in resources as the mosquito physiology is geared toward insecticide resistance; and 2) it is possible that insecticide resistance genes have a pleiotropic effect on genes associated with immunity. Similar outcomes have been observed in other insecticide resistant mosquito populations [79] and may be in response to the oxidative burden generated by $\mathrm{P} 450$ metabolism (as the prophenoloxidase cascade is also associated with oxidative stress) [80]. The CLIP proteins, along with trypsin and chymotrypsin like proteins have previously been implicated in mosquito immunity against Plasmodium [81], and recently RNAi mediated silencing of the serine protease, ClipC9, was shown to result in enhanced numbers of midgut oocysts [82].

Based on previous reports, a suite of ten detoxification enzyme genes were selected for assay by qPCR in An. gambiae. Such a strategy for testing metabolic resistance is better suited to an African context where expensive and highly technical assays are not always feasible due to lack of resources and funding. A suite of 10 genes was selected for testing metabolic resistance mechanisms in An. gambiae. The GST, GSTS1-2, showed the highest over-transcription with 31- and 7.6-fold increases in males and females respectively, followed by GSTe2, TPX 2 and CYP6M2, the orthologue of CYP6M7 in An. funestus.

A number of genes that were tested in An. gambiae showed only slight over-transcription despite having been significantly over-transcribed in other reports. This serves to highlight the fact that insecticide resistant populations of different Anopheles species and from different localities employ a multi-faceted system for protection. From this point of view, the testing of redox-associated transcripts is difficult. They play a critical role in resistance but as highlighted by Bonizzoni et al. [75], different enzymes are over-transcribed in different populations.

\section{Conclusion}

To date, limited information is available on the molecular mechanisms of insecticide resistance in the DRC, a country with a severe malaria burden. In the north-eastern part of the country, high levels of pyrethroid resistance were present. Fortunately, organophosphates remain effective and this work emphasizes the need for continued surveillance, and avoidance of a one-size-fits-all approach to vector control and insecticide resistance management.

\section{Additional file}

Additional file 1. Anopheles funestus annotations of the microarray reporter sequences. 


\section{Abbreviations}

ace- $1^{R}$ : acetylcholinesterase mutation; CYP: cytochrome P450; DDT: dichlorodiphenyltrichloroethane; DRC: Democratic Republic of Congo; ELISA: enzymelinked immunosorbent assay; GABA: $\gamma$-amino butyric acid; GST: glutathiones-transferase; IRS: indoor residual spraying; kdr: knockdown resistance; LLINs: long-lasting insecticide treated bed nets; PCR: polymerase chain reaction; PBO: piperonyl butoxide; qPCR: real-time quantitative PCR; RG: reference gene; RR: homozygous resistant; RS: heterozygous resistant; TPX: thioredoxin peroxidase; VGSC: voltage gated sodium channel; WHO: World Health Organization.

\section{Authors' contributions}

LN contributed to the design of the study, conducted the laboratory work, assisted with analyses, and wrote the manuscript. $\mathrm{RHH}$ arranged and performed the field collections and bioassays, and commented on and approved the manuscript. YLDM assisted with microarray experiments and provided comments on the manuscript. NC performed the microarray analyses, and commented on and approved the manuscript. RNC designed the microarray platform. MC assisted with bioassays, commented on and approved the manuscript. LLK conceptualized the project, assisted with laboratory bioassays, analysis and drafting of paper, provided comments on and approved the manuscript. All authors read and approved the final manuscript.

\section{Author details}

${ }^{1}$ Wits Research Institute for Malaria, School of Pathology, Faculty of Health Sciences, University of the Witwatersrand, Johannesburg 2000, South Africa. ${ }^{2}$ Centre for Emerging, Zoonotic \& Parasitic Diseases, National Institute for Communicable Diseases, Johannesburg 2131, South Africa. ${ }^{3}$ Department of Genetics, Forestry and Agricultural Biotechnology Institute, University of Pretoria, Pretoria 0028, South Africa.

\section{Acknowledgements}

The authors thank the reviewers for feedback and helpful comments for improvement of the manuscript.

\section{Competing interests}

The authors declare that they have no competing interests.

\section{Availability of data and materials}

Data are included in this published article and its additional information files: Additional file 1.

\section{Consent for publication}

Not applicable.

\section{Ethics approval and consent to participate}

Not applicable.

\section{Funding}

DST/NRF South African Research Chairs Initiative to MC; PDP/NRF and NRF Competitive Research Funding for Rated Researchers to LLK.

\section{Publisher's Note}

Springer Nature remains neutral with regard to jurisdictional claims in published maps and institutional affiliations.

Received: 29 July 2017 Accepted: 28 October 2017

Published online: 07 November 2017

\section{References}

1. Mouchet J, Manguin S, Sircoulon J, Laventure S, Faye O, Onapa AW, et al. Evolution of malaria in Africa for the past 40 years: impact of climatic and human factors. J Am Mosq Control Assoc. 1998;14:121-30.

2. Martens $\mathrm{P}$, Hall L. Malaria on the move: human population movement and malaria transmission. Emerg Infect Dis. 2000;6:103-9.

3. WHO. World Malaria Report 2015. Geneva: World Health Organization; 2016
4. Bobanga T, Umesumbu SE, Mandoko AS, Nsibu CN, Dotson EB, Beach $\mathrm{RF}$, et al. Presence of species within the Anopheles gambiae complex in the Democratic Republic of Congo. Trans R Soc Trop Med Hyg. 2016;110:373-5.

5. Kelly-Hope LA, Molyneux DH, Bockarie MJ. Can malaria vector control accelerate the interruption of lymphatic filariasis transmission in Africa; capturing a window of opportunity? Parasit Vectors. 2013;6:39.

6. WHO. Global plan for insecticide resistance management. Geneva: World Health Organization; 2012.

7. Etang J, Nwane P, Mbida JA, Piameu M, Manga B, Souop D, et al. Variations of insecticide residual bio-efficacy on different types of walls: results from a community-based trial in south Cameroon. Malar J. 2011;10:333.

8. Chanda E, Chanda J, Kandyata A, Phiri FN, Muzia L, Haque U, et al. Efficacy of ACTELLIC 300 CS, pirimiphos methyl, for indoor residual spraying in areas of high vector resistance to pyrethroids and carbamates in Zambia. J Med Entomol. 2013;50:1275-81.

9. Agossa FR, Aïkpon R, Azondékon R, Govoetchan R, Padonnou GG, Oussou $\mathrm{O}$, et al. Efficacy of various insecticides recommended for indoor residual spraying: pirimiphos methyl, potential alternative to bendiocarb for pyrethroid resistance management in Benin, West Africa. Trans R Soc Trop Med Hyg. 2014;108:84-91.

10. Tchicaya ES, Nsanzabana C, Smith TA, Donze J, de Hipsl ML, Tano Y, et al. Micro-encapsulated pirimiphos-methyl shows high insecticidal efficacy and long residual activity against pyrethroid-resistant malaria vectors in central Cote d'Ivoire. Malar J. 2014;13:332.

11. WHO. World malaria report 2014. Geneva: World Health Organization; 2015

12. Oduola AO, Idowu ET, Oyebola MK, Adeogun AO, Olojede JB, Otubanjo $\mathrm{OA}$, et al. Evidence of carbamate resistance in urban populations of Anopheles gambiae s.s. mosquitoes resistant to DDT and deltamethrin insecticides in Lagos, South-Western Nigeria. Parasit Vectors. 2012;5:116

13. Essandoh J, Yawson AE, Weetman D. Acetylcholinesterase (Ace-1) target site mutation 1195 is strongly diagnostic of carbamate and organophosphate resistance in Anopheles gambiae s.s. and Anopheles coluzzii across southern Ghana. Malar J. 2013;12:404.

14. Jones CM, Liyanapathirana M, Agossa FR, Weetman D, Ranson H, Donnelly MJ, et al. Footprints of positive selection associated with a mutation (N1575Y) in the voltage-gated sodium channel of Anopheles gambiae. Proc Natl Acad Sci USA. 2012;109:6614-9.

15. Martinez-Torres D, Chandre F, Williamson MS, Darriet F, Berge JB, Devonshire AL, et al. Molecular characterization of pyrethroid knockdown resistance $(k d r)$ in the major malaria vector Anopheles gambiae s.s.. Insect Mol Biol. 1998:7:179-84.

16. Ranson H, Jensen B, Vulule JM, Wang X, Hemingway J, Collins FH. Identification of a point mutation in the voltage-gated sodium channel gene of Kenyan Anopheles gambiae associated with resistance to DDT and pyrethroids. Insect Mol Biol. 2000;9:491-7.

17. Verhaeghen K, Van Bortel W, Roelants P, Backeljau T, Coosemans M. Detec tion of the East and West African kdr mutation in Anopheles gambiae and Anopheles arabiensis from Uganda using a new assay based on FRET/Melt Curve analysis. Malar J. 2006;5:16.

18. Koekemoer LL, Spillings BL, Christian RN, Lo TC, Kaiser ML, Norton RA, et al. Multiple insecticide resistance in Anopheles gambiae (Diptera: Culicidae) from Pointe Noire, Republic of the Congo. Vector Borne Zoonotic Dis. 2011;11:1193-200.

19. Brooke BD. $k d r$ : can a single mutation produce an entire insecticide resistance phenotype? Trans R Soc Trop Med Hyg. 2008;102:524-5.

20. Nardini L, Christian RN, Coetzer N, Ranson H, Coetzee M, Koekemoer LL. Detoxification enzymes associated with insecticide resistance in laboratory strains of Anopheles arabiensis of different geographic origin. Parasit Vectors. 2012;5:113.

21. Matowo J, Kitau J, Kaaya R, Kavishe R, Wright A, Kisinza W, et al. Trends in the selection of insecticide resistance in Anopheles gambiae s.l. mosquitoes in northwest Tanzania during a community randomized trial of longlasting insecticidal nets and indoor residual spraying. Med Vet Entomol. 2015;29:51-9.

22. Nwane $P$, Etang J, Chouaïbou M, Toto JC, Mimpfoundi R, Simard F. $K d r$-based insecticide resistance in Anopheles gambiae s.s. populations in Cameroon: spread of L1014F and L1014S mutations. BMC Res Notes. 2011;4:463. 
23. Aizoun N, Aïkpon R, Akogbeto M. Evidence of increasing L1014F kdr mutation frequency in Anopheles gambiae s.l. pyrethroid resistant following a nationwide distribution of LLINs by the Beninese National Malaria Control Programme. Asian Pac. J Trop Biomed. 2014:4:239-43.

24. Ibrahim SS, Manu YA, Tukur Z, Irving H, Wondji CS. High frequency of $k d r$ L1014F is associated with pyrethroid resistance in Anopheles coluzzii in Sudan savannah of northern Nigeria. BMC Infect Dis. 2014;14:441.

25. Diabaté A, Baldet T, Chandre F, Dabire KR, Simard F, Ouedraogo JB, et al. First report of a $k d r$ mutation in Anopheles arabiensis from Burkina Faso, West Africa. J Am Mosq Control Assoc. 2004;20:195-6.

26. Santolamazza F, Calzetta M, Etang J, Barrese E, Dia I, Caccone A, et al. Distribution of knock-down resistance mutations in Anopheles gambiae molecular forms in west and west-central Africa. Malar J. 2008;7:74.

27. Weill M, Malcolm C, Chandre F, Mogensen K, Berthomieu A, Marquine $M$, et al. The unique mutation in ace-1 giving high insecticide resistance is easily detectable in mosquito vectors. Insect Mol Biol. 2004;13:1-7.

28. Dabire RK, Namountougou M, Diabate A, Soma DD, Bado J, Toe HK, et al. Distribution and frequency of $k d r$ mutations within Anopheles gambiae s.l. populations and first report of the ace.1 G119S mutation in Anopheles arabiensis from Burkina Faso (West Africa). PLoS ONE. 2014;9:e101484.

29. Djogbenou L, Dabiré R, Diabaté A, Kengne P, Akogbeto M, Hougard JM, et al. Identification and geographic distribution of the $A C E-1 R$ mutation in the malaria vector Anopheles gambiae in south-western Burkina Faso, West Africa. Am J Trop Med Hyg. 2008;78:298-302.

30. Ahoua Alou LP, Koffi AA, Adja MA, Tia E, Kouassi PK, Kone M, et al. Distribution of ace-1R and resistance to carbamates and organophosphates in Anopheles gambiae s.s. populations from Cote d'Ivoire. Malar J. 2010;9:167.

31. Aïkpon R, Sezonlin M, Osse R, Akogbeto M. Evidence of multiple mechanisms providing carbamate and organophosphate resistance in field An. gambiae population from Atacora in Benin. Parasit Vectors. 2014;7:568.

32. Du W, Awolola TS, Howell P, Koekemoer LL, Brooke BD, Benedict MQ, et al. Independent mutations in the $R d$ l locus confer dieldrin resistance to Anopheles gambiae and An. arabiensis. Insect Mol Biol. 2005;14:179-83.

33. Wondji CS, Dabiré RK, Tukur Z, Irving H, Djouaka R, Morgan JC. Identification and distribution of a GABA receptor mutation conferring dieldrin resistance in the malaria vector Anopheles funestus in Africa. Insect Biochem Mol Biol. 2011;41:484-91.

34. Riveron JM, Yunta C, Ibrahim SS, Djouaka R, Irving H, Menze BD, et al. A single mutation in the GSTe2 gene allows tracking of metabolically based insecticide resistance in a major malaria vector. Genome Biol. 2014;15:R27.

35. Mitchell SN, Stevenson BJ, Müller P, Wilding CS, Egyir-Yawson A, Field SG, et al. Identification and validation of a gene causing cross-resistance between insecticide classes in Anopheles gambiae from Ghana. Proc Natl Acad Sci USA. 2012;109:6147-52.

36. Chiu TL, Wen Z, Rupasinghe SG, Schuler MA. Comparative molecular modeling of Anopheles gambiae CYP6Z1, a mosquito P450 capable of metabolizing DDT. Proc Natl Acad Sci USA. 2008;105:8855-60.

37. Djouaka RF, Bakare AA, Coulibaly ON, Akogbeto MC, Ranson H, Hemingway J, et al. Expression of the cytochrome P450s, CYP6P3 and CYP6M2 are significantly elevated in multiple pyrethroid resistant populations of Anopheles gambiae s.s. from Southern Benin and Nigeria. BMC Genom. 2008;9:538.

38. Edi CV, Djogbenou L, Jenkins AM, Regna K, Muskavitch MA, Poupardin $R$, et al. CYP6 P450 enzymes and ACE-1 duplication produce extreme and multiple insecticide resistance in the malaria mosquito Anopheles gambiae. PLoS Genet. 2014;10:e1004236.

39. Jones CM, Haji KA, Khatib BO, Bagi J, Mcha J, Devine GJ, et al. The dynamics of pyrethroid resistance in Anopheles arabiensis from Zanzibar and an assessment of the underlying genetic basis. Parasit Vectors. 2013;6:343.

40. Matowo J, Jones CM, Kabula B, Ranson H, Steen K, Mosha F, et al. Genetic basis of pyrethroid resistance in a population of Anopheles arabiensis, the primary malaria vector in Lower Moshi, north-eastern Tanzania. Parasit Vectors. 2014;7:274.

41. Riveron JM, Ibrahim SS, Chanda E, Mzilahowa T, Cuamba N, Irving H, et al. The highly polymorphic CYP6M7 cytochrome P450 gene partners with the directionally selected CYP6P9a and CYP6P9b genes to expand the pyrethroid resistance front in the malaria vector Anopheles funestus in Africa. BMC Genom. 2014;15:817.
42. Christian RN, Strode C, Ranson H, Coetzer N, Coetzee M, Koekemoer LL. Microarray analysis of a pyrethroid resistant African malaria vector, Anopheles funestus, from southern Africa. Pest Biochem Physiol. 2011;99:140-7.

43. Gillies MT, Coetzee M. A supplement to the Anophelinae of Africa south of the Sahara (Afrotropical Region). Publ S. Afr Inst Med Res. 1987;55:12-36.

44. Scott JA, Brogdon WG, Collins FH. Identification of single specimens of the Anopheles gambiae complex by the polymerase chain reaction. Am J Trop Med Hyg. 1993;49:520-9.

45. Favia G, Lanfrancotti A, Spanos L, Siden-Kiamos I, Louis C. Molecular characterization of ribosomal DNA polymorphisms discriminating among chromosomal forms of Anopheles gambiae s.s.. Insect Mol Biol. 2001;10:19-23.

46. Koekemoer LL, Kamau L, Hunt RH, Coetzee M. A cocktail polymerase chain reaction assay to identify members of the Anopheles funestus (Diptera: Culicidae) group. Am J Trop Med Hyg. 2002;66:804-11.

47. Wirtz RA, Duncan JF, Njelesani EK, Schneider I, Brown AE, Oster CN, et al. ELISA method for detecting Plasmodium falciparum circumsporozoite antibody. Bull World Health Organ. 1989;67:535-42.

48. Durnez L, Van Bortel W, Denis L, Roelants P, Veracx A, Trung HD, et al. False positive circumsporozoite protein ELISA: a challenge for the estimation of the entomological inoculation rate of malaria and for vector incrimination. Malar J. 2011;10:195.

49. WHO. Test procedures for inecticide resistance monitoring in malaria vector mosquitoes. Geneva: World Health Organization; 2016.

50. Bass C, Nikou D, Vontas J, Donnelly MJ, Williamson MS, Field LM. The vector population monitoring tool (VPMT): high-throughput DNA-based diagnostics for the monitoring of mosquito vector populations. Malar Res Treat. 2010;2010:190434.

51. Nardini L, Christian RN, Coetzer N, Koekemoer LL. DDT and pyrethroid resistance in Anopheles arabiensis from South Africa. Parasit Vectors. 2013;6:229.

52. Bustin SA, Benes V, Garson JA, Hellemans J, Huggett J, Kubista M, et al. The MIQE guidelines: minimum information for publication of quantitative real-time PCR experiments. Clin Chem. 2009;55:611-22.

53. Anderson $C L$, Jensen $J$, Omtoft TF. Normalization of real-time quantitative reverse transcription-PCR data: a model-based variance estimation approach to identify genes suited for normalization, applied to bladder and colon cancer data sets. Cancer Res. 2004;64:5245-50.

54. Pfaffl MW. A new mathematical model for relative quantification in realtime RT-PCR. Nucleic Acids Res. 2001;29:e45.

55. Smythe GK. Limma: linear models for microarray data. New York: Springer 2005.

56. The R Project for Statistical Computing. [https://www.r-project.org/]. Accessed 28 July 2017.

57. NCBI Batch Entrez. [https://www.ncbi.nlm.nih.gov/sites/batchentrez]. Accessed 28 July 2017.

58. Conesa A, Gotz S, Garcia-Gomez JM, Terol J, Talon M, Robles M. Blast2GO: a universal tool for annotation, visualization and analysis in functional genomics research. Bioinformatics. 2005;21:3674-6.

59. Altschul SF, Gish W, Miller W, Myers EW, Lipman DJ. Basic local alignment search tool. J Mol Biol. 1990;215:403-10.

60. Vectorbase. [https://www.vectorbase.org/]. Accessed 28 July 2017.

61. Ciechanover A, Orian A, Schwartz AL. Ubiquitin-mediated proteolysis: biological regulation via destruction. BioEssays. 2000;22:442-51.

62. Herranz R, Mateos J, Marco R. Diversification and independent evolution of troponin C genes in insects. J Mol Evol. 2005;60:31-44.

63. Weedall GD, Irving H, Hughes MA, Wondji CS. Molecular tools for studying the major malaria vector Anopheles funestus: improving the utility of the genome using a comparative poly(A) and Ribo-Zero RNAseq analysis. BMC Genom. 2015;16:931.

64. Basilua Kanza JP, El Fahime E, Alaoui S, el Essassi M, Brooke B, Nkebolo Malafu A, et al. Pyrethroid, DDT and malathion resistance in the malaria vector Anopheles gambiae from the Democratic Republic of Congo. Trans R Soc Trop Med Hyg. 2013;107:8-14.

65. Wondji CS, Irving H, Morgan J, Lobo NF, Collins FH, Hunt RH, et al. Two duplicated $\mathrm{P} 450$ genes are associated with pyrethroid resistance in Anopheles funestus, a major malaria vector. Genome Res. 2009;19:452-9.

66. Riveron JM, Irving H, Ndula M, Barnes KG, Ibrahim SS, Paine MJ, et al. Directionally selected cytochrome P450 alleles are driving the spread of 
pyrethroid resistance in the major malaria vector Anopheles funestus. Proc Natl Acad Sci USA. 2013;110:252-7.

67. Riveron JM, Chiumia M, Menze BD, Barnes KG, Irving H, Ibrahim SS, et al. Rise of multiple insecticide resistance in Anopheles funestus in Malawi: a major concern for malaria vector control. Malar J. 2015;14:344.

68. Coetzee M, Koekemoer LL. Molecular systematics and insecticide resistance in the major African malaria vector Anopheles funestus. Annu Rev Entomol. 2013;58:393-412.

69. Riveron JM, Osae M, Egyir-Yawson A, Irving H, Ibrahim SS, Wondji CS. Multiple insecticide resistance in the major malaria vector Anopheles funestus in southern Ghana: implications for malaria control. Parasit Vectors. 2016;9:504

70. David JP, Strode C, Vontas J, Nikou D, Vaughan A, Pignatelli PM, et al. The Anopheles gambiae detoxification chip: a highly specific microarray to study metabolic-based insecticide resistance in malaria vectors. Proc Natl Acad Sci USA. 2005;102:4080-4.

71. Lumjuan N, McCarroll L, Prapanthadara LA, Hemingway J, Ranson H. Elevated activity of an Epsilon class glutathione transferase confers DDT resistance in the dengue vector, Aedes aegypti. Insect Biochem Mol Biol. 2005:35:861-71.

72. Riveron JM, Ibrahim SS, Mulamba C, Djouaka R, Irving H, Wondji MJ. Genome-wide transcription and functional analyses reveal heterogeneous molecular mechanisms driving pyrethroids resistance in the major malaria vector Anopheles funestus across Africa. G3 (Bethesda). 2017;7:1819-32.

73. Yan H, Jia H, Gao H, Guo X, Xu B. Identification, genomic organization, and oxidative stress response of a sigma class glutathione $S$-transferase gene (AccGSTS1) in the honey bee, Apis cerana cerana. Cell Stress Chaperones. 2013:18:415-26.

74. Müller P, Donnelly MJ, Ranson H. Transcription profiling of a recently colonised pyrethroid resistant Anopheles gambiae strain from Ghana. BMC Genom. 2007:8:36.

75. Bonizzoni M, Afrane Y, Dunn WA, Atieli FK, Zhou G, Zhong D, et al. Comparative transcriptome analyses of deltamethrin-resistant and -susceptible Anopheles gambiae mosquitoes from Kenya by RNA-Seq. PLoS ONE. 2012;7:e44607.
76. Gregory R, Darby AC, Irving H, Coulibaly MB, Hughes M, Koekemoer LL, et al. A de novo expression profiling of Anopheles funestus, malaria vector in Africa, using 454 pyrosequencing. PLoS ONE. 2011;6:e17418.

77. Wood O, Hanrahan S, Coetzee M, Koekemoer L, Brooke B. Cuticle thickening associated with pyrethroid resistance in the major malaria vector Anopheles funestus. Parasit Vectors. 2010;3:67.

78. Rivero A, Vezilier J, Weill M, Read AF, Gandon S. Insecticide control of vector-borne diseases: when is insecticide resistance a problem? PLoS Pathog. 2010;6:e1001000.

79. David JP, Faucon F, Chandor-Proust A, Poupardin R, Riaz MA, Bonin A, et al. Comparative analysis of response to selection with three insecticides in the dengue mosquito Aedes aegypti using mRNA sequencing. BMC Genom. 2014;15:174.

80. Moreno-Garcia M, Recio-Totoro B, Claudio-Piedras F, Lanz-Mendoza H. Injury and immune response: applying the danger theory to mosquitoes. Front Plant Sci. 2014:5:451.

81. Volz J, Osta MA, Kafatos FC, Muller HM. The roles of two clip domain serine proteases in innate immune responses of the malaria vector Anopheles gambiae. J Biol Chem. 2005;280:40161-8.

82. Mitri C, Markianos K, Guelbeogo WM, Bischoff E, Gneme A, Eiglmeier K, et al. The kdr-bearing haplotype and susceptibility to Plasmodium falciparum in Anopheles gambiae: genetic correlation and functional testing. Malar J. 2015;14:391.

83. Munhenga G, Koekemoer LL. Differential expression of cytochrome P450 genes in a laboratory selected Anopheles arabiensis colony. Afr J Biotechnol. 2011;10:12741-6.

84. Amenya DA, Naguran R, Lo TC, Ranson H, Spillings BL, Wood OR, et al. Over expression of a cytochrome P450 (CYP6P9) in a major African malaria vector, Anopheles funestus, resistant to pyrethroids. Insect Mol Biol. 2008;17:19-25.

\section{Submit your next manuscript to BioMed Central and we will help you at every step:}

- We accept pre-submission inquiries

- Our selector tool helps you to find the most relevant journal

- We provide round the clock customer support

- Convenient online submission

- Thorough peer review

- Inclusion in PubMed and all major indexing services

- Maximum visibility for your research

Submit your manuscript at www.biomedcentral com/submit 